\title{
Energy project financing in the GCC region: an empirical investigation
}

\author{
Tarek Atalla ${ }^{1} \cdot$ Maria Chiara D'Errico ${ }^{2}$
}

Received: 12 June 2017 / Accepted: 17 June 2019 / Published online: 31 July 2019

(c) The Author(s) 2019

\begin{abstract}
This paper analyzes the capital structure of energy infrastructure projects in the Gulf Cooperation Council region, where energy projects form the bulk of the deal-making backload. The econometric estimation of 108 energy project finance for the period 2005-2014 valued at 258 bn USD sheds the light on the success factors for such projects in the region, confirming the relevant relationships among project size, owner concentration and debt duration. The analysis illustrates the roles that debt, equity, interest rate, and the economic crisis play in the financial structuring of infrastructure projects in rapidly growing emerging markets. First, it confirms that longer debt duration is correlated with higher debt ratio. Second, it shows that larger project size is correlated with lower debt ownership concentration. Third, the financial crisis had a different effect on debt ratio and debt duration. Fourth, project size and interest rate are negatively correlated, although regional specific patterns would emerge when comparing the effects of the 2008 financial crisis on interest rates. These findings have several multilevel implications for regulators, debt issuers and investors. For regulators, findings amplify the way in which to improve debt issuance in GCC countries. For issuers, findings suggest that they should be more concerned about the bonds' security and seniority as the firm-specific characteristics, such as size and debt and equity concentration of finance project, affect the capital structure. For investors, the study offers an analytical framework to investigate bonds' structure before investing.
\end{abstract}

Keywords Gulf Cooperation Council $\cdot$ Project finance $\cdot$ Shariah-compliant financing $\cdot$ Energy infrastructure

\section{Introduction}

The Gulf Cooperation Council ${ }^{1}$ (GCC) region comprises fast-growing economies with government revenues fueled by sizeable oil rents which are characterized by administrated consumer energy prices. Investment in energy infrastructures is a crucial pillar of the GCC Governments policy strategies for regional economic development. Furthermore, GCC economies have usually specific tax legislations that can influence the capital structure of large investment projects. With the exception of Oman, ${ }^{2}$ GCC countries did not historically levy sizable corporate tax on locally owned domestic companies [2]. However, foreign investors face taxes that vary from 5 to $30 \%$ for non-hydrocarbon-related projects and can reach up to $85 \%$ for projects relating to

\footnotetext{
Tarek Atalla

tatalla@outlook.com

Maria Chiara D'Errico

mariachiara.derrico@unipg.it

1 KAPSARC, Riyadh, Saudi Arabia

2 University of Perugia, Perugia, Italy
}

hydrocarbon production [32]. In addition, these countries have also accumulated assets from oil revenues ${ }^{3}$ over a number of years, which are now used partly for macro-economic stabilization in periods of high oil price volatility.

In this framework, project finance is favored by both private and governmental financial entities. International investors have an incentive to invest in the GCC region by taking an equity stake in projects, which limits their corporate tax exposure. At the same time, project finance is favored by governmental financial entities in the region, to better shelter their assets management strategies, as shown by the importance of the financial flows involved.

\footnotetext{
1 The member states of GCC include the monarchies of Bahrain, Kuwait, Oman, Qatar, Saudi Arabia, and the United Arab Emirates.

${ }^{2}$ Corporate tax rate is $12 \%$ for all corporations regardless of the extent of foreign participation.

${ }^{3}$ As of October 2014, the Sovereign Wealth Fund Institute estimates the total reserve funds controlled by the GCC at 2590 Billion USD equivalent, about $37 \%$ of the world's funds and $61.5 \%$ of funds raised through oil and gas activities (Project finance journal). After the oil price downturn of December 2014, the sharp reduction in oil revenues led to a sharp asset withdrawal in the order of $30 \%$ in 20152016, to finance Governments' needs.
} 
Similar to other capital-intensive projects, energy infrastructure projects in GCC regions are typically funded through a combination of project finance and government incentives. Finnerty [24] defines project finance as the raising of funds to finance economically separable capital investment projects, where the project cash flow serves as the source of funds to service loans and provide returns on the equity invested in the project. This form of financing allows project developers to obtain the highest leverage possible for a project's funding and relies on the expected cash flows of the projects rather than the balance sheets of the investors. Each project has specific debt and equity ratios, ownership concentrations and durations that vary depending on the project's characteristics. The impact of risk on project finance leverage is assessed by Byoun et al. [12].

In the last decade, the vast amounts invested through project finance in the GCC have exceeded the region's economic weight. For the period 2005-2014, the world ratio of total project finance investment to GDP averaged around $0.6 \%$ globally. This ratio was $5.4 \%$ for the GCC, with a total of $\$ 404$ billion invested.

Surprisingly, there is no previously published research analyzing the issue. This paper fills this gap by developing a comprehensive empirical analysis of the capital structure of energy infrastructure projects in the GCC regions. While the determinants of the issuers' choice of different financial instruments have been explored widely in western capital markets, little is known about their impact on GCC capital markets. Indeed, despite the development of the GCC capital markets and the increasing interest among issuers in project finance, it is still largely unknown why some firms still choose to consider this financial instrument instead of relying on conventional bonds. The objective of this research is to analyze the significance of the determinants of capital structure of 108 projects in the GCC that achieved financial closure between 2005 and 2014. The 108 projects considered represent a total investment of \$258 billion and span over six industrial sectors: utilities (power generation and water desalination), oil and gas production, petrochemicals and downstream, renewable power generation ${ }^{4}$, and mining.

Our study improves in different ways the current literature on the GCC capital markets. First, we depict the capital structure of each project computing their leverage, duration, interest rate, debt, and equity ownership concentration. Second, we collect variables depicting the agency and information costs of each project; these variables are assumed to be the main explanatory variables of the leverage ratio. Finally, we test the significance of these variables in conditioning the capital structure of finance project and analyze the effects

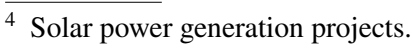

of information and agency costs on capital structure using different linear regression models.

Results show that the size of finance project is negatively correlated with the debt concentration ownership and the interest rate; debt duration instead, positively affects the debt ratio. Moreover, we observe that the 2008-2009 financial crisis had no univocal effect on the debt ratio and duration of the GCC projects.

The paper is structured as follow: "Literature" section provides a theoretical background to motivate the empirical investigation. "Model and data description" section provides a description of the data and methodology used for this analysis and gives an overview of the variables used in the empirical regression. "Results and discussion" section presents the results of the cluster and econometric analysis and "Conclusion" section provides the policy implications of our research. Equations used in the regression and intermediate results are attached in "Appendix".

\section{Literature}

The theoretical background of the capital structure's determinants originated with the very influential work of Modigliani and Miller [44] in which the authors showed that a firm's value is not related to its individual capital structure. The theorem the two authors developed states that a firm or an investor would be entirely indifferent about any decision concerning funding, and that the capital structure choices come with no cost. The argument is based on the assumption of perfect capital markets with no taxes, no transaction and financial distress costs, homogeneous expectations among investors and complete information available to all. In a perfect word, with perfect capital, managers would be indifferent about the sources of financing. However, the conclusion that only cash generated by the firm's operations determines its value does not seem to work at all.

Starting from the capital structure irrelevance theorem of Modigliani and Miller [44], the interest of the academic world to understand firm's capital structure shaped additional theories by relaxing the four main assumptions of Modigliani and Miller. According to the Trade-off theory, leverage comes with several costs, such as bankruptcy costs, loss of non-debt tax shields and agency costs (see, e.g., De Angelo and Masulis [16], Bradley et al. [9] and Meyers [46]). The theory states that there is a trade-off between the costs and benefits of leverage and thus there is a perfect mix of debt and equity to be achieved. The firm tries to exploit the benefits of tax deductible interest payments by taking on more debt which are offset by the cost of bankruptcy or financial distress that increases with more debt. Therefore, the firm wants to find its optimal capital structure in a way that keeps tax payments at a minimum level whilst also 
keeping the cost and probability of financial distress as low as possible.

In a non-perfect capital market, the firm is not only subject to taxes and costs of financial distress but it also has to deal with agency costs and costs generated by imperfect information. Thus, acknowledging those costs means relaxing the latter two assumptions made by Modigliani and Miller. Agency theory teaches us that managers and investors do not always share the same incentives [35]. More recent studies extend the initial model by introducing the possibility of selfish management which accepts projects if these increase personal benefits rather than company value. Therefore, outside investors will always charge a higher interest to compensate for the possibility of too little, asymmetric or wrong information.

In addition to agency costs, there are costs due to asymmetric information between informed managers and investors who have limited information. According to Myers and Majluf [46] incomplete information can lead to underinvestment; firms cannot raise enough money through equity issuance to the public since investors know less about the company's investment opportunities than the firm's managers. The existence of information asymmetry is the starting point of the well-known Pecking order theory. Firms will always prefer internally generated funds to external sources of funding since the former are not subjected to any information asymmetry. Only if all internal sources are depleted firms would issue safe debt and only if absolutely necessary they would resort to equity issuance. The Pecking order theory also entails that companies do not have an optimal debt-equity mix [46]. Mayer [46] points out that the theory is in no way able to explain every capital structure decision and could therefore easily be rejected since there are plenty of cases in which companies issued equity even though they could have tapped internal funds or at least have issued investment-grade debt.

Over the last 50 years, the theories behind capital structure choices have evolved. Today we face a number of theories that sometimes complement each other but often suggest competing solutions to the capital structure puzzle. The theories find support in numerous empirical studies that analyze the capital structure choice, providing mixed results.

Many empirical studies have investigated the effects that firm-specific factors have on capital structure. Those factors include amongst others, the firm's size, profitability and growth opportunities (most prominently [48, 53]). Every measure and the expected sign can be motivated in line with the main theories.

The trade-off theory suggests a clear positive relationship between firm size and leverage. Rajan and Zingales [48] describe the firm size as a proxy for the inverse probability of bankruptcy. This means that larger companies are less likely to face the costs of financial distress or as Bevan and Danbolt [6] call it are "too big to fail". Same conclusion has been reached in Degryseet al. [18], since larger firms tend to be more diversified and show less-volatile earnings. Cantillo and Wright [14] provide evidence that larger companies with large issue size and more profitable firms, use public debt. Krishnaswami et al. [38] show a positive relationship between growth opportunities and the use of private debt. Conversely, Houston and James [34] document a negative relationship for firm which has a single bank relationship.

Ganguli [25] uses the data of 81 Indian companies from 2004 to 2009 in an attempt to investigate relationship between capital structure and ownership structure of a firm. Grounded on the Agency theory, the paper suggests that the ownership structure impacts capital structure but not the vice versa. Consistent with the theoretical prediction, the paper also reveals that leverage is positively related to concentrated shareholding and has a negative relation with diffuseness of shareholding after controlling for profitability, risk, tangibility, growth and size. Lin et al. [41] study the relationship between borrowing firm's ownership structure and its choice of sourcing debt. Their findings provide evidence that the divergence between control rights and cash flow rights of a borrowing firm's largest ultimate owner has negative impact on the firm's reliance on bank debt financing. In addition, firms controlled by large shareholders with excess control rights, may choose public debt financing over bank debt as a way of avoiding scrutiny and insulating themselves from bank monitoring. Jiraporn et al. [39] use agency theory to investigate the influence of CEO dominance on variation in capital structure. Due to agency conflicts, managers may not always adopt leverage choices that maximize shareholders' value. Consistent with the prediction of agency theory, the evidence reveals that when the CEO plays a more dominant role, the firm adopts significantly lower leverage, probably to evade the disciplinary mechanisms associated with debt financing. Therefore, CEO power matters to critical corporate outcomes such as capital structure decisions. In addition, they found that the impact of changes in capital structure on firm's performance is more negative for firms with more powerful CEOs.

One can notice the scarcity of specific research pertaining to the capital structure determinants of energy-related project finance, both from theoretical and empirical perspectives. Ghoddushi and Khoshroo [27] and [8] provide a brief overview of the major forms of Islamic finance methods used in the energy sector, reviewing the existing experiences of energy sector. However, this study does not provide an analytical framework.

Azmat et al. [5] analyze the factors affecting an issuer's choice of Islamic bond structure as compared to conventional financial instruments applying an ordered probit 
model techniques to a sample of Malaysian Islamic bonds. Results suggest that there are some significant differences in the determinants of issuer's choice between Islamic and conventional bond due to the characteristics specific to Islamic bonds; unlike conventional bonds, the stock valuation of the issuer does not impact debt-equity targets with Islamic joint venture bond issuance. Grassa and Miniaoui [29] use instead an econometric method to investigate the determinants of an issuer's financing choice between the Islamic bond structure and the conventional bonds instruments. Results suggest that the choice is affected by firm-specific characteristics and that the older and larger firms prefer conventional bonds rather than Islamic bonds. Nevertheless, this former study has a broad extending scope that does not consider the sectorspecific characteristic of the energy sector. Furthermore, Corielli et al. [15] analyze the capital structure and cost of debt financing for a large set of projects, concluding that lenders favor non-financial contracts to reduce project risk and agency costs.

\section{Model and data description}

Following the main theories of capital structure, we investigate the effect that firm-specific factors have on capital structure of energy project finance of GCC regions using econometric techniques.

The starting analytical model expresses the leverage as a function of project-specific factors representing the related agency and information costs as follows:

$L=f\left(x_{1}, x_{2}, \ldots, x_{k}\right)$

where $L$ is the leverage and is expressed as a function of $k$ variables $x_{1}, x_{2}, \ldots, x_{k}$ representing the ownership and information structure of each project. We investigate different aspects of project leverage using the debt ratio, debt and equity ownership concentration as dependent variables expressing the capital structure. On the right hand side, the determinants conditioning the structure of leverage (along with the variables previously listed), encompass the project size, the debt duration and a dummy variable representing financial crisis of 2008-2009.

We assumed a linear functional form, leading to the following econometric specification:

$y_{s}=x_{1} \beta_{1}+x_{2} \beta_{2}+\cdots+x_{k} \beta_{k}+\varepsilon$

where $\varepsilon$ is the standard normally distributed error term and $y_{s}$ with $s=1, \ldots, 4$ are the four dependent variables: debt ratio, debt duration, debt and equity ownership concentration index. The specification of each linear regression model is shown in the "Appendix".
We collected primary data on 108 energy infrastructure projects in the GCC region, for the period 2005-2014. ${ }^{5} \mathrm{We}$ recorded the main project characteristics, relying mainly on transaction data in the database from the Infrastructure Journal and Project Finance Magazine. ${ }^{6}$ We subsequently checked this information against data on project finance deals from Thomrson Reuters DataStream, especially for debt ratios and interest rates. We further corroborated the projects' characteristics with information obtained through local specialized press ${ }^{7}$ and updated only when discrepancies appeared. We did not include re-financing or asset acquisition projects and we made all efforts to consider only financially closed projects. Bridge or caveat loans transactions are not part of the sample, as they are usually temporary arrangements ${ }^{8}$ pending agreements on the longer-term financing of the project. The earliest incorporated project is the upgrade of Bahrain's Sitra Refinery, sanctioned in February 2005. The most recent project is Sipchem's Jubail Acetyls Complex signed in April 2014.

The GCC energy project finance database, classified by type and country, is shown in Table 1. Projects spanning several countries are attributed to the country with the largest stake. ${ }^{9}$ There are 93 Greenfield projects and 15 projects representing an expansion of existing infrastructure.

The constructed GCC database is a representative sample of economic activity in the region's booming sectors. Around $40 \%$ of the projects in the database are in the Kingdom of Saudi Arabia, the largest economy in the region. Qatar and the United Arab Emirates each share about 20\% of the projects, with most of their projects achieving financial closure after the 2008 crisis. The utilities, oil and gas and petrochemicals sectors form the bulk of the financing deals, consistently with the economic structure of the region.

The GCC database includes relevant variables for the empirical analysis. The debt ratio is defined as the proportion of secured senior debt to the project's total value, as agreed upon at the financial closure date. In conformity with Pierru [47], this includes Islamic and bank loans, export agencies' credit lines, bonds and sponsor loans.

According to Yescombe [57], a typical debt ratio in project finance is around 0.7 for a power plant project with no

\footnotetext{
5 Petroleum extraction was not included in the dataset, as most of these projects are implemented by national oil companies that have no recourse to project finance.

${ }^{6}$ Last retrieved on June 2014.

${ }^{7}$ Generated from both English and Arabic written press.

8 The duration of a bridge loan typically varies between couple of months to 3 years. An example is the Borouge 2 Petrochemicals Expansion bridge loan signed mid-2007 in the UAE.

${ }^{9}$ For example, Dolphin Energy, shared across Oman, Qatar and UAE, is attributed to UAE, since Emirati entities hold the largest stake in the project's equity.
} 
Table 1 Project counts by infrastructure types and country

\begin{tabular}{lccccccc}
\hline Type of project & $\begin{array}{l}\text { Number of } \\
\text { projects }\end{array}$ & $\begin{array}{l}\text { Saudi } \\
\text { Arabia }\end{array}$ & Oman & UAE & Bahrain & Kuwait & Qatar \\
\hline $\begin{array}{l}\text { Utilities (Power and water, renewable } \\
\text { excluded) }\end{array}$ & 37 & 14 & 7 & 8 & 3 & 1 & 6 \\
Oil and gas & 20 & 2 & $2 *$ & $7 *$ & 1 & 0 & $10^{*}$ \\
Petrochemicals & 28 & 19 & 3 & 0 & 1 & 2 & 3 \\
Renewable power generation & 2 & 1 & 0 & 1 & 0 & 0 & 0 \\
Transportation & 5 & 3 & 2 & 0 & 0 & 0 & 0 \\
Mining & 16 & 4 & 1 & 8 & 2 & 0 & 1 \\
Total & 108 & 43 & 13 & 17 & 7 & 3 & 10 \\
Out of which : expansion & 15 & 6 & 2 & 3 & 1 & 0 & 3 \\
\hline
\end{tabular}

Country values with $(*)$ include the transnational Dolphin Gas project, which is accounted for once when counting the type of projects

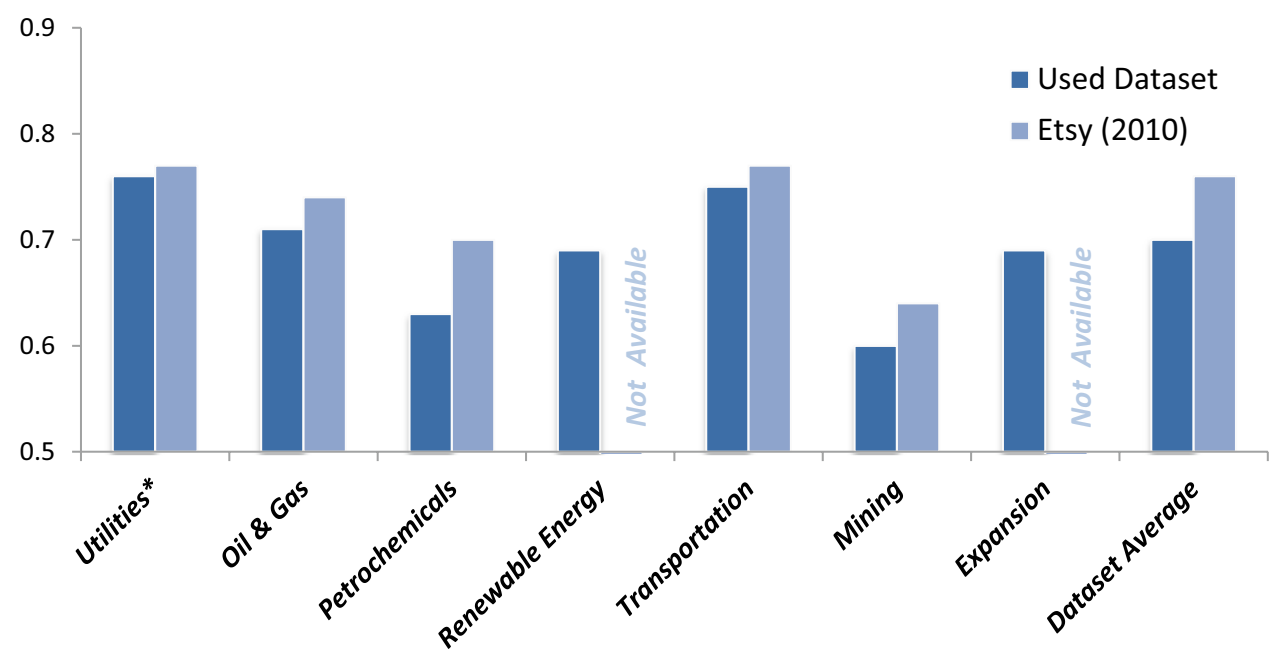

Fig. 1 Comparison of average debt ratios for project finance ventures between the GCC data set and Etsy (2010) price hedging or offtake contract, 0.8 for a transport concession and 0.5 for a natural resources project. The 2011 survey of European energy transmission infrastructure projects undertaken by the consultancy firm Roland Berger found average debt ratios ranging from 0.6 to 0.7 . Lubin and Esty [42] shows that from 2005 to 2009, the global average debt-equity ratio was 0.76 and the power sector had a leverage ratio of 0.77 . The ratios for oil and gas, petrochemicals, mining and water and sewage were $0.74,0.70,0.64$ and 0.77 , respectively. Wagenvoort et al. [55] show that the 2006-2009 EU average debt ratio was 0.79 for utilities and 0.77 for transportation projects. In comparison, our data set shows similar debt ratios for utilities $(0.76)$ and transportation (0.75), yet lower ratios for oil and gas (0.71), petrochemicals (0.63) and mining (0.60). In addition, both the expansion and renewables projects had an average debt ratio of 0.69. The average debt ratio for our pool of data stands is approximately 0.7 . Figure 1 below represents the profile of our data set and compares it with Esty [22, 42].
The project size is measured in dollars. Larger capitalintensive projects usually require more financing parties and have more diverse equity ownership [51]. Loans for such projects tend to be medium- to long-term, always exceeding 15 years [20]. In the GCC, large multi-billion dollar projects, especially in strategic sectors such as oil and gas or utilities, are usually backed by governmental or state-owned entities in joint ventures with international service and technology providers. This structure translates into lower interest rates on associated loans since the projects have strong sponsors.

The concentration in equity ownership, quantified using the Herfindhal Index (HI), is defined as the sum of the squares of each equity ownership ratio. In our sample, the HI values vary between 0.11 (Financing of the J5 Nakilat RasGas LNG Vessels) and unity. Project finance enterprises have concentrated equity ownership, typically with two large supporting entities owning a majority of the equity [21]. Concentrated ownership helps to reduce agency and transaction costs [23, 43, 47]. Figure 2 shows the distribution of 


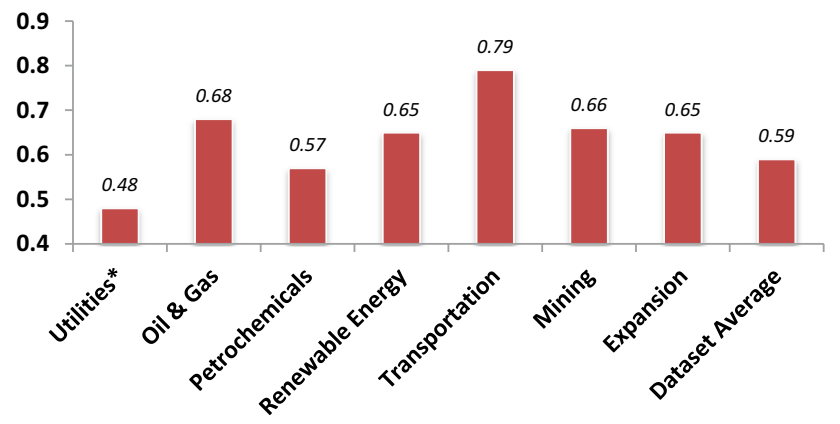

Fig. 2 Distribution of average equity concentration among sectors in the used data set. (*) The utilities sector includes both electricity generation and water desalination and distribution

Herfindhal equity concentration among sectors in our data set.

Debt ownership concentration is also computed using the HI. Generally, large multi-billion dollar projects have lower concentration of debt ownership, since lenders do not wish to invest large sums in one project due to diversification concerns [26]. Debt ownership tends to be more concentrated in the power, transportation and oil and gas industries, which are typically characterized by large syndicated debt deals $[37,49]$. Furthermore, in countries with strong law enforcement mechanisms, lenders tend to create smaller, concentrated syndicates to reduce administrative costs and efforts [23]. In countries with weak legal institutions, lenders favor comprehensive syndicates.

We consider the GCC country risk, using the OECD Country Risk Index, rating GCC countries for the period 2005-2013. Byoun and Chu [11] ascertain that projects located in countries with weak political institutions are characterized by limited government involvement to avoid political influence. This usually translates into less involvement from state-owned enterprises and a lower ownership concentration with diversified private sector partnerships. In addition to financial and military risk, the index takes into account the probability of a force majeure event and the risk of government restriction on capital transfer or foreign exchange. ${ }^{10}$ This yearly classification ranges from 0 to 7 , with 0 the lowest risk and 7 the highest. The GCC countries are classified as relatively stable economies if their ratings vary between 3 and 6 for the duration of the sample. The lowest risk is in Bahrain; the highest is in Qatar. While only the results using OECD's Country Risk ratings were reported, we considered Moody's ratings of sovereign debt for the five countries and obtained similar results. The

\footnotetext{
$\overline{10}$ The OECD compares this classification to the country ceilings issued by major credit rating agencies.
}

value of the country risk is considered at the project's date of financial closure.

We quantify the lending interest rate of each project, representative of the project's perceived risk. Deesomak et al. [17] state that emerging economies have a higher perceived country risk, leading to higher risk premiums. Loans denominated in local currency have even higher interest rates. Girardone and Snaith [28] found evidence that lower political risks result in cheaper project finance loans, especially in emerging economies. They find that loan spreads are negatively related to the effectiveness, quality and strength of a country's legal and institutional systems. Lower levels of government stability and democratic accountability are associated with higher loan spreads. The database uses the $\mathrm{LIBOR}^{11}$ interest rate + cost of funds or the fixed interest rate when provided. Some rates were reported in $\mathrm{SIBOR}^{12}$ (Islamic loans) or EURIBOR ${ }^{13}$; these were converted into LIBOR by adding the difference between the rates. The LIBOR was then converted into a fixed interest rate by taking the prevailing LIBOR rates at the date of financial closure.

We also compute the duration of the loan, considering it after financial closure of the deal. When there are multiple loan tranches, we calculated the average of the various debt durations weighted by their proportion of the total debt. Bridge loans were not considered part of the loan duration in our analysis. Buscaino et al. [10] find that the loan duration does not play a significant role in determining a project's debt ratio for advanced economies. Unlike in corporate finance, where risky firms seem to borrow in the middle of the maturity range [30], project finance allows longer debt durations with risks shared among sponsors and various types of investors [1, 26, 50]. Most project finance enterprises are engineered to have stand-alone profitability, resulting in higher bond ratings attractive to large institutional investors. This is typical of public-private partnerships in the GCC utility sectors, where fixed feed-in tariffs and buy agreements guarantee a competitive rate of return [3, 45]. Furthermore, West [56] mentions that financial institutions are reluctant to engage in long-horizon project loans without government backing, especially in emerging economies, suggesting that Islamic financing may be an ideal medium for project finance in the resource sector.

The 2008-2009 financial crisis had a sizeable impact on energy prices and, by association, on the development of energy and non-energy infrastructure [54]. Warring investing parties slowed lending activities, causing economic instability. The financial crisis has increased uncertainty as

\footnotetext{
${ }^{11}$ London Interbank Offered Rate.

12 Saudi Interbank Offered Rate.

13 Euro Interbank Offered Rate.
} 
Table 2 Summary table for projects' variables

\begin{tabular}{|c|c|c|c|c|c|c|c|}
\hline & Debt ratio & Expansion & Value in $\mathrm{B} \$$ & $\begin{array}{l}\text { Herfindhal } \\
\text { equity }\end{array}$ & Herfindhal Debt & Post-crisis & Duration \\
\hline Utilities (non-renewable) & 0.76 & 4 & 53.1 & 0.48 & 0.29 & 19 & 19.2 \\
\hline Oil and gas & 0.71 & 2 & 74.0 & 0.68 & 0.23 & 9 & 12.3 \\
\hline Petrochemicals & 0.63 & 5 & 86.2 & 0.57 & 0.16 & 10 & 12.9 \\
\hline Renewable energy & 0.69 & 0 & 1.2 & 0.65 & 0.6 & 2 & 18.0 \\
\hline Transportation & 0.75 & 1 & 3.7 & 0.79 & 0.21 & 2 & 14.1 \\
\hline Mining & 0.60 & 3 & 38.9 & 0.66 & 0.37 & 10 & 13.2 \\
\hline Expansion (taken as subset) & 0.69 & - & 31.3 & 0.65 & 0.35 & 7 & 12.4 \\
\hline Total & 0.69 & 15 & 257.2 & 0.59 & 0.26 & 52 & 15.1 \\
\hline
\end{tabular}

well as costs due to asymmetric information that discourage funding through equity issuance. We therefore expect that crisis, as increasing the uncertainty, leads companies towards lower capitalization and higher debt. Moreover, many studies in the literature consider the impact of the financial crisis on the stream of project finance [7, 26, 55]. We also incorporate the crisis into the GCC project finance analysis.

We represent the crisis with a dummy variable, taking the collapse of Lehman Brothers (September 15th, 2008) as the starting point [47]. We used this dummy variable as a slope-shifter for the total value, debt duration, debt and equity ownership concentration and OECD rating. We capture the specific features pertaining to project finance infrastructure category with a qualitative variable. We define a 0-1 dummy variable for each of the six project types. Another dummy variable distinguishes projects that are as extensions of existing ones, with 0 given to Greenfield and 1 given to Brownfield projects.

The summary statistics of the GCC project variables are shown in Table 2.

We perform cross-sectional regression on the dependent variables against a set of explanatory variables using a stepwise procedure. We removed all non-significant variables in successive iterations until all variables were within a $10 \%$ significance level, indicating that we had reached the most parsimonious model. Along with traditional ordinary least square (OLS) estimation, we performed the two stages least squares (TSLS) and generalized method of moments (GMM) analyses to deal with possible endogeneity and heteroskedasticity problems [4, 33]. Indeed, the last two methods use only the explanatory variables that are not correlated with error term $\varepsilon$ to compute the parameter estimates. We use "internal" instruments based on the lags of first differences of the instrumented variables. This estimator is feasible for general application where researchers usually have limited access to quality instruments.

\section{Results and discussion}

\section{Cluster analysis}

We study how the determinants of capital structure differ among projects in an effort to characterize the leading dependent variables for the empirical regression, using cluster analysis. The analysis considers the total value, concentration of debt and equity ownership, debt duration, country rating and the crisis dummy variable. A $K$-mean clustering method was applied using a Euclidean dissimilarity measure with a variance ratio criterion [13] to find the ideal number of clusters. This lead to an ideal cluster number of four. The results of the analysis are represented in Fig. 3 below and detailed characteristics for each group are illustrated in Table 5 in the "Appendix".

The first group, centered on the Jubail Seamless Tube Mill, is defined by a small project size ( $<\$ 1$ Billion), a shorter debt duration ( $\sim 12$ years) and roughly two equal partners in both equity and debt ownership. Financial closure for most of these projects occurred after the 2008-2009 global crisis. These are mostly small petrochemical plants or localized regional utility projects.

The second group, centered on Qatargas III, is characterized by medium-sized projects ( $\$ 6$ Billion), very low debt ownership concentration (0.1), high concentration of equity ownership, and post-crisis financial closure. Debt duration for this cluster is similar to the overall sample average (16 years). The bulk of the group consists of mining projects, such as ore extraction, smelters and large LNG liquefaction projects such as QatarGas.

The third group, concentrated around Ma'aden's Rolling Mill, is characterized by relatively lower project size (\$2-3 Billion), the highest debt and equity ownership concentration $(>0.6)$ and the longest debt duration (18 years). Most of these projects were finalized after the crisis. The largest subset of the group consists of utility-sector ventures in power generation and water desalination. This 


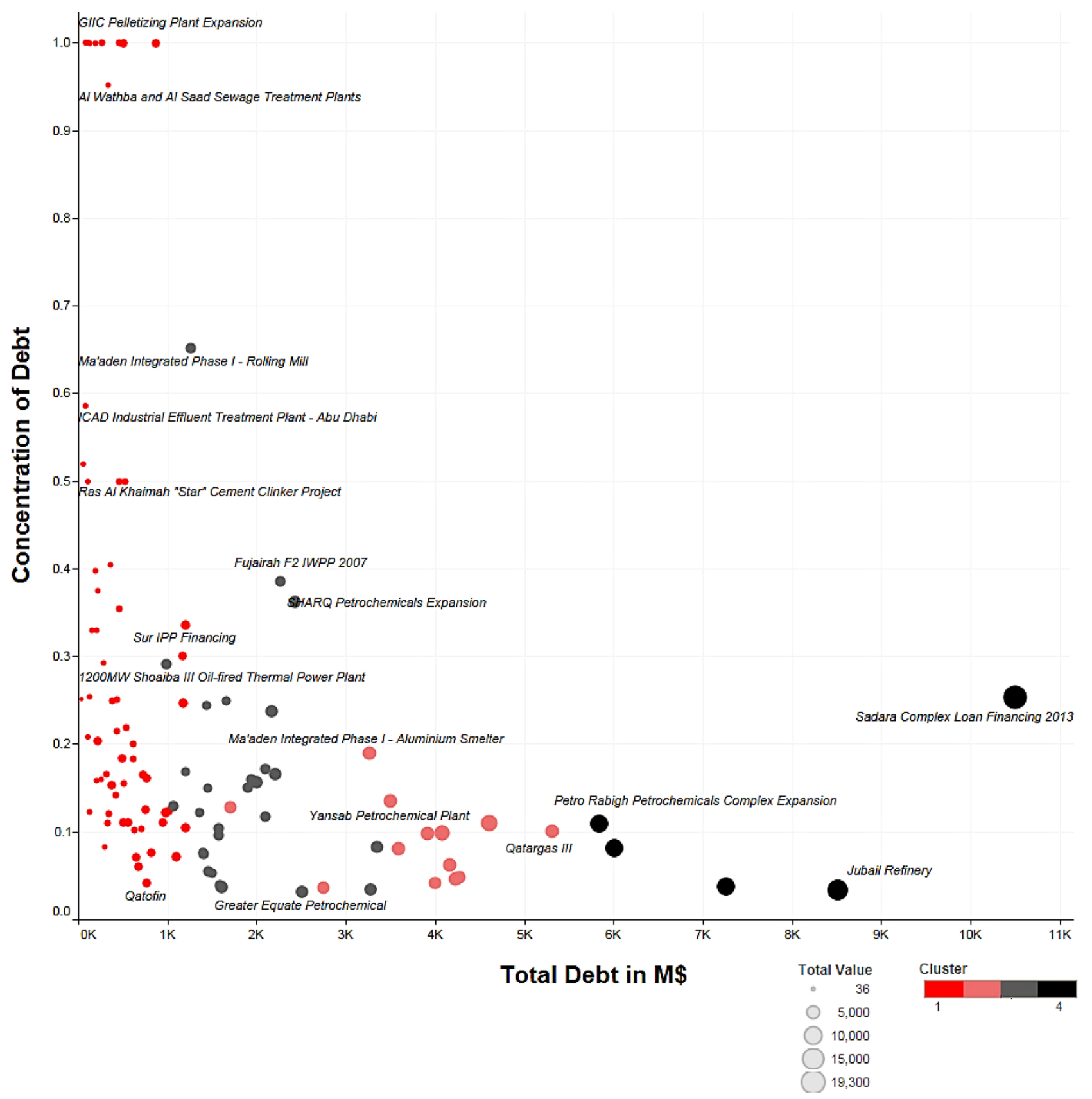

Fig. 3 Cluster analysis of the projects using debt concentration and total debt value

group also includes a few medium-sized petrochemical expansion projects.

The fourth and final group, highlighted by the Jubail refinery, is categorized by very large total project values (> \$10 Billion), very low concentration of debt ownership (around 0.033), roughly two equal partners in equity ownership, an average debt duration and financial closure dates occurring after the financial crisis. These mostly consist of Saudi-based, high-cost, long-lead refineries and petrochemical complexes that were launched after 2010 in a bid for downstream diversification.

\section{Econometric analysis and results}

Given the agency cost and incomplete information theoretical framework, we want to verify the following assumptions:

$H_{1} \quad$ A longer debt duration has a positive increasing effect on the debt ratio 
Table 3 Regression results for the debt ratio, average debt duration, debt concentration and equity concentration as the dependent variables [The TSLS and the GMM methods allow to bypass endogene-

\begin{tabular}{|c|c|c|c|c|}
\hline & Debt ratio & Avg. Debt duration & Debt concentration & Equity concentration \\
\hline \multirow[t]{3}{*}{$\mathrm{C}$} & OLS $[+, * * *]$ & OLS $[+, * * *]$ & OLS $[+, * * *]$ & OLS $[+, * * *]$ \\
\hline & TSLS $[+, * * *]$ & TSLS $[+]$, & $\operatorname{TSLS}[+, * * *]$ & $\operatorname{TSLS}[+, * * *]$ \\
\hline & $\operatorname{GMM}[+, * * *]$ & $\operatorname{GMM}[+, *]$ & GMM $[+, * * *]$ & GMM $[+, * * *]$ \\
\hline \multirow[t]{3}{*}{ AVG_DURATION_DEBT } & OLS $[+, * * *]$ & N/A & - & OLS $[-, * * *]$ \\
\hline & TSLS $[+, * * *]$ & N/A & - & TSLS $[-, * * *]$ \\
\hline & $\mathrm{GMM}[+, * * *]$ & N/A & - & GMM $[-, * * *]$ \\
\hline \multirow[t]{3}{*}{ CRISIS } & OLS $[+, * * *]$ & OLS $[-, * * *]$ & - & OLS $[-, * *]$ \\
\hline & TSLS $[+, * * *]$ & TSLS $[-, * * *]$ & - & TSLS $\left[-,{ }^{*}\right]$ \\
\hline & $\mathrm{GMM}[+, * * *]$ & GMM $[-, * * *]$ & - & GMM $[-, * *]$ \\
\hline \multirow[t]{3}{*}{ CRISIS*LOG(TOTAL_VALUE) } & OLS $[-, * * *]$ & OLS $[+, * * *]$ & - & - \\
\hline & TSLS $[-, * * *]$ & $\operatorname{TSLS}[+, * * *]$ & - & - \\
\hline & GMM $[-, * * *]$ & GMM $[+, * * *]$ & - & - \\
\hline \multirow[t]{3}{*}{ CRISIS*HERF_DEBT } & OLS $[-, * * *]$ & - & - & OLS $[+, * *]$ \\
\hline & TSLS $[-, * * *]$ & - & - & $\operatorname{TSLS}[+, *]$ \\
\hline & GMM $[-, * * *]$ & - & - & GMM $[+, * * *]$ \\
\hline \multirow[t]{3}{*}{ DEBT_RATIO } & N/A & OLS $[+, * * *]$ & - & - \\
\hline & N/A & $\operatorname{TSLS}[+, * * *]$ & - & - \\
\hline & N/A & GMM $[+, * * *]$ & - & - \\
\hline \multirow[t]{3}{*}{ HERF_EQ } & - & OLS $[-, * * *]$ & - & N/A \\
\hline & - & TSLS $[-, * * *]$ & - & N/A \\
\hline & - & $\mathrm{GMM}[-, * * *]$ & - & N/A \\
\hline \multirow[t]{3}{*}{ LOG(TOTAL_VALUE) } & - & - & OLS $[-, * * *]$ & - \\
\hline & - & - & TSLS $[-, * * *]$ & - \\
\hline & - & - & GMM $[-, * * *]$ & - \\
\hline \multirow[t]{3}{*}{ CRISIS*DEBT_RATIO } & - & - & OLS $[-, * * *]$ & - \\
\hline & - & - & TSLS $[-, * *]$ & - \\
\hline & - & - & GMM $[-, *]$ & - \\
\hline \multirow[t]{3}{*}{ CRISIS*HERF_EQ } & - & - & OLS $[+, * * *]$ & - \\
\hline & - & - & TSLS $[+, * * *]$ & - \\
\hline & - & - & $\operatorname{GMM}[+, * * *]$ & - \\
\hline
\end{tabular}

OLS, TSLS, and GMM mean ordinary least square, two-stage least square and general methods of moments, respectively. The symbols $* * *, * *$, and $*$ represent significance values of $1 \%, 5 \%$ and $10 \%$, respectively

$\mathrm{H}_{2}$ The debt concentration is negatively correlated to the project size

$H_{3}$ The financial crisis leads to the increase of the debt ratio and the reduction of the debt duration

$H_{4}$ The interest rate is negatively correlated to the project size

Longer debt duration and higher debt concentration reflect changing in information and agency costs. A wide time-period of the debt reflects the stability of the relationships among financing institutions as well as a restricted debt ownership concentration reflects a greater information about the partners involved in the project. We applied the linear model in Eq. (1) to the four dependent variables previously described. The results of the successive OLS, TSLS ity problems that may occurred when we used variables as dependent and then as explanatory variable.] 
Table 4 Descriptive table of averages for selected variables

\begin{tabular}{lcccllccc}
\hline Type of project & Project count & Debt ratio & $\begin{array}{l}\text { Value in } \\
\text { Bn } \$\end{array}$ & $\begin{array}{l}\text { Herfindhal } \\
\text { equity concen- } \\
\text { tration }\end{array}$ & $\begin{array}{l}\text { Herfindhal debt Post-crisis } \\
\text { concentration }\end{array}$ & Duration Interest rate * \\
\hline Utilities & 25 & 0.79 & 36.27 & 0.42 & 0.22 & 10 & 20.3 & 427 \\
Oil and gas & 13 & 0.72 & 57.73 & 0.69 & 0.1 & 5 & 13.1 & 186 \\
Petrochemicals & 16 & 0.61 & 63.67 & 0.61 & 0.12 & 4 & 13.6 & 126 \\
Mining & 8 & 0.56 & 26.48 & 0.67 & 0.32 & 5 & 14.8 & 223 \\
Total & 62 & 0.67 & 184.15 & 0.5975 & 0.19 & 6 & 15.45 & 169 \\
Out of which : expansion & 6 & 0.67 & 18.16 & 0.69 & 0.36 & 6 & 14.3 \\
\hline
\end{tabular}

(*) defined as average basis points (bp) over LIBOR

that the longer the debt duration, the higher the debt ratio. A long repayment period means lower annual debt service and, therefore, a higher debt service-to-coverage ratio (the ratio of the project's cash flow to debt interest and principal). This makes possible a higher debt ratio. Institutional investors who feel comfortable increasing the leverage of a project are confident about the long-term solvency of a project's assets. Guedes and Opler [30] found similar results for corporate debt, showing that investors avoid long-term lending to risky firms (and projects, by association) to avoid inefficient liquidation and risky asset substitution in case of default.

Results show that the crisis affected the debt ratio, as the 'crisis' dummy variable has a positive coefficient with a $1 \%$ significance level. The variables 'crisis* $\log ($ total_value)' and 'crisis*Herf_debt' have negative coefficients, meaning that these variables influenced the debt ratio after the crisis, but had no influence before. Although the size of the project and the concentration debt are assumed to be positively correlated with leverage, the negative sign is essentially due to the prevalence of the effect of the crisis that, increasing the incomplete information costs, has negative effect. In the case of project size, the post-crisis correlation may reflect greater risk aversion for large assets that would be difficult to liquidate. In the case of debt ownership concentration, when many lenders share the risk (low debt concentration), they can collectively lend a larger total amount (higher debt ratio).

The significance of debt concentration post-crisis may also be a sign of GCC government intervention after the crisis that helped increase market liquidity, guaranteeing many debts in the process. Moreover, many of the projects were initiated by semi-governmental or government-backed institutions. Furthermore, the post-crisis period (2009-2013) saw sustained high crude oil prices that increased market liquidity while reducing borrowing interest rates, making it more advantageous for project developers to leverage debt.

The OECD country risk rating and its crisis slope are not significant at the $10 \%$ level, as shown in Table 6 . The adjusted R-squared is around 0.26 throughout the OLS iterations and the subsequent TSLS and GMM. The TSLS is typically used to correct for simultaneous equation bias affecting OLS. The GMM is a more general application for this type of data as it is not known whether these methods are strictly normal or involve uncertainty in the data distribution.

The debt duration is negatively related to equity ownership concentration and positively related to debt ratio, both at a $1 \%$ significance level (Table 3, col. 2). The variable 'crisis' also has a large negative coefficient (around -12), meaning that financial markets moved toward shorter debt durations after the onset of the financial crisis [19]. The instability brought on by the financial crisis may have led to a perceived reduction in the project assets' salability, making banks reluctant to extend long-term loans for fear of lack of liquidity. Furthermore, GCC long-term projects have strong governmental backing, usually represented in the form of government joint ventures with leading international service companies. This structure became more common after the crisis, with more government involvement reflected in the positive coefficient of the variable 'crisis*project_size'. Debt ratio is also negatively correlated with debt maturity date, which is characteristic of government-backed projects in the region.

The negative correlation of debt concentration with debt ownership concentration shown in Fig. 3 is consistent with the literature, as Sorge [51] found that larger projects have more diverse debt ownership.

The equity ownership concentration is inversely related to debt duration and crisis (Table 3, col. 4), which is aligned with the results of the cluster analysis shown in Fig. 3. As the debt duration increases, equity ownership becomes more diversified to reduce risks for private-sector lenders. Moreover, the crisis reduced equity ownership concentration, meaning that lending entities sought to reduce their exposure by sharing risks with other banks. On the other side, the product "crisis*debt concentration', which looks at the impact of the crisis on debt concentration, is positively correlated with equity ownership concentration, meaning debt concentration increased after 
the crisis. This result demonstrates government backing for projects post-crisis, making up for private sector restraint in investment. All of the variables are significant at the $1 \%$ level, except crisis which is significant at the 5\% level.

We conducted a further investigation on the determinants of debt interest rates in project finance, based on a subset of the GCC data set, limited to 62 projects due to a lack of data availability. Table 4 shows descriptive summary details of the sub-sample (which lacks renewable or transportation projects, since there are few of these in the original dataset).

The regression results show that interest rate is negatively correlated with debt duration, the logarithm of the project size as well as the 'petrochemicals' and 'expansion' dummy variables (see "Appendix", Table 10). Lower interest rates are typical of large government capital investments in long-lead projects with extended debt maturity dates. This is especially true for petrochemical and expansion projects and it is consistent with the results shown in Tables 5 and in the "Appendix", Table 10). Furthermore, the interaction of 'crisis' with 'country rating' and 'debt ownership concentration' shows positive correlation with the interest rate, meaning that a decrease in a country's rating after the crisis corresponded to an increase in interest rates. This was accompanied by an increase in debt ownership concentration after the crisis, which is representative of the government backing of projects. Leigland and Russell [40] mention that the financial crisis decreased the available liquidity for financing projects in emerging economies, leading to higher lending interest rates. However, their paper does not study command-based economies with the government spending levels characteristic of the GCC. All of the variables are significant at the $1 \%$ level, except for the dummy expansion which is significant at the 5\% level. The adjusted R-squared value is 0.69 .

\section{Conclusion}

This research analyzes the determinants of capital structure of 108 projects in the GCC that achieved financial closure between 2005 and 2014 through regression estimation. The results show the impact of several financial indicators on project finance in the fast-growing, resourcedriven economies of the GCC. The analysis illustrates the roles that debt, equity, interest rate and the economic crisis played in the financial structuring of infrastructure projects in rapidly growing emerging markets and affirms our four hypotheses. First, it confirms that longer debt duration is correlated with higher debt ratio. Second, it shows that larger project size is correlated with lower debt ownership concentration. Third, project size and interest rate are negatively correlated. Fourth, the financial crisis had a different effect on debt ratio and debt duration in the GCC compared to the rest of the world.

Reviewing the recent economic literature, these results constitute a novel interpretation of the relationship between financial market indicators, agents' behavior and attitude toward energy project finance in the GCC. There are two policy implications derived from the empirical analysis.

First, it can help private financial agents make qualified investment decisions and therefore guide policy-makers in establishing supportive market regulations. This seems to be the spirit of the recent strategic long-term plan enacted by the Saudi government (KSA VISION 2030) [36] that focuses on liberalization, privatization and providing liquidity for enduring public-private partnerships.

Second, this market analysis can form a basis for wider implementation of project finance as a reliable way to standardize and further popularize Shariah-compliant financing. Indeed, value creation through risk-sharing, while sheltering resources from the capital structure of the financing entity, is a principal characteristic of project financing and is coherent with the anti-usury concept of Islamic financing. Finally, there is additional room for improvement in term of regulatory framework to achieve a balanced growth of the overall GCC debt security market. As more data become available and project finance spread in new sectors, one can investigate further by testing if industry-specific variables affect the capital structure at firm level.
Table 5 Descriptive results of the cluster analysis

\begin{tabular}{lllllll}
\hline Central objects & \multicolumn{7}{l}{} & & & \\
\hline Cluster & Cluster size & Total value & $\begin{array}{l}\text { Debt con- } \\
\text { centration }\end{array}$ & $\begin{array}{l}\text { Equity con- } \\
\text { centration }\end{array}$ & $\begin{array}{l}\text { Average duration } \\
\text { of Debt (years) }\end{array}$ & Crisis \\
\hline $\begin{array}{l}\text { (Jubail Seamless } \\
\quad 62\end{array}$ & 670 & 0.50 & 0.50 & 12.0 & 1 \\
$\begin{array}{l}\text { Steel Tube Mill) } \\
\text { (Qatargas III) }\end{array}$ & 14 & 5800 & 0.10 & 0.58 & 16.0 & 0 \\
3 (Ma'aden & 28 & 2519 & 0.65 & 0.62 & 18.00 & 1 \\
$\quad \begin{array}{l}\text { Integrated Phase } \\
\text { I-Rolling Mill) }\end{array}$ & & & & & & 1 \\
4 (Jubail Refinery) & 5 & 14,042 & 0.03 & 0.53 & 15.5 & 1 \\
\hline
\end{tabular}


Table 6 Results of iterative regressions of debt ratio (coefficients and standard errors)

\begin{tabular}{|c|c|c|c|c|c|}
\hline Dependent: debt ratio & OLS iteration 1 & OLS iteration 2 & OLS iteration 3 & TSLS & GMM \\
\hline \multirow[t]{2}{*}{$\mathrm{C}$} & 0.21 & $0.51 * * *$ & $0.51 * * *$ & $0.48 * * *$ & $0.47 * * *$ \\
\hline & 0.22 & 0.04 & 0.04 & 0.049 & 0.03 \\
\hline \multirow[t]{2}{*}{ AVG_DURATION_DEBT } & $0.014 * * *$ & $0.013 * * *$ & $0.01 * * *$ & $0.01 * * *$ & $0.01 * * *$ \\
\hline & 0.01 & 0.01 & 0.01 & 0.01 & 0.01 \\
\hline \multirow[t]{2}{*}{ CRISIS } & $0.76 * * *$ & $0.46^{* * * *}$ & $0.33 * * *$ & $0.35 * * *$ & $0.36 * * *$ \\
\hline & 0.26 & 0.14 & 0.11 & 0.13 & 0.07 \\
\hline \multirow[t]{2}{*}{ CRISIS*LOG(TOTAL_VALUE) } & $-0.06 * *$ & $-0.05 * * *$ & $-0.05 * * *$ & $-0.05 * * *$ & $-0.05 * * *$ \\
\hline & 0.02 & 0.01 & 0.01 & 0.02 & 0.01 \\
\hline \multirow[t]{2}{*}{ CRISIS*HERF_DEBT } & $-0.23 * *$ & $-0.16^{* *}$ & $-0.15^{* *}$ & -0.13 & $-0.12 * * *$ \\
\hline & 0.10 & 0.07 & 0.07 & 0.09 & 0.04 \\
\hline \multirow[t]{2}{*}{ CRISIS*OECD_RATING } & $-0.15 * *$ & -0.04 & - & - & - \\
\hline & 0.08 & 0.03 & - & - & - \\
\hline \multirow[t]{2}{*}{ OECD_RATING } & 0.11 & - & - & - & - \\
\hline & 0.07 & - & - & - & - \\
\hline \multirow[t]{2}{*}{ HERF_DEBT } & 0.05 & - & - & - & - \\
\hline & 0.07 & - & - & - & - \\
\hline \multirow[t]{2}{*}{ LOG(TOTAL_VALUE) } & 0.01 & - & - & - & - \\
\hline & 0.02 & - & - & - & - \\
\hline \multirow[t]{2}{*}{ CRISIS*HERF_EQ } & 0.06 & - & - & - & - \\
\hline & 0.1 & - & - & - & - \\
\hline \multirow[t]{2}{*}{ CRISIS*AVG_DURATION_DEBT } & -0.00 & - & - & - & - \\
\hline & 0.01 & - & - & - & - \\
\hline \multirow[t]{2}{*}{ HERF_EQ } & -0.02 & - & - & - & - \\
\hline & 0.06 & - & - & - & - \\
\hline Adjusted R-squared & 0.25 & 0.27 & 0.26 & 0.26 & 0.25 \\
\hline Durbin-Watson Stat & 2.37 & 2.25 & 2.24 & 2.21 & 2.20 \\
\hline
\end{tabular}

OLS, TSLS and GMM mean ordinary least square, two-stage least square and general methods of moments, respectively. The symbols $* * *, * *$, and $*$ represent significance at $1 \%, 5 \%$, and $10 \%$, respectively

Open Access This article is distributed under the terms of the Creative Commons Attribution 4.0 International License (http://creativeco mmons.org/licenses/by/4.0/), which permits unrestricted use, distribution, and reproduction in any medium, provided you give appropriate credit to the original author(s) and the source, provide a link to the Creative Commons license, and indicate if changes were made.

\section{Appendix: Detailed results of the empirical analysis}

\section{Results of cluster analysis}

\section{Determinants of debt ratio}

The determinants of debt ratio have been analyzed using the same iterative procedure explained in "Conclusion" section. Resuming Eq. 1 in "Determinants of Debt Ratio" section, the debt ratio is treated as a function of a set of explanatory variables, as follows:
Debtratio $_{i}=\alpha+\beta_{1}$.AverageDurationDebt ${ }_{i}$

$$
\begin{aligned}
& +\beta_{2} \cdot \text { Crisis }_{i}+\beta_{3} \cdot \log \left(\text { projectsize }_{i}\right) \\
& +\beta_{4} \text {.OwnershipConcentration }_{i} \\
& +\beta_{5} \text {.DebtConcentration }{ }_{i} \\
& +\beta_{6} \text {. CountryRating } j \\
& +\beta_{7} \text {.Crisis }_{i} * \text { CountryRating }_{j} \\
& +\beta_{8} \text {.Crisis }_{i} * \text { OwnershipConcentration }_{i} \\
& +\beta_{9} \text {.Crisis }_{i} \\
& \text { * DebtConcentration }{ }_{i}
\end{aligned}
$$

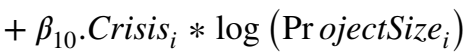

$$
\begin{aligned}
& +\beta_{11} \text {.Crisis }_{i} \\
& \text { * AverageDurationDebt } t_{i}+v_{i}
\end{aligned}
$$


Table 7 Results of iterative regressions of Average Debt Duration (coefficients and standard errors)

\begin{tabular}{|c|c|c|c|c|}
\hline Dependent: average debt duration & Iteration 1 & Iteration 2 & TSLS & GMM \\
\hline \multirow[t]{2}{*}{ CRISIS*LOG(TOTAL_VALUE) } & $2.90 * * *$ & $1.79 * * *$ & $1.81 * * *$ & $1.70 * * *$ \\
\hline & 0.82 & 0.44 & 0.54 & 0.40 \\
\hline \multirow[t]{2}{*}{ DEBT_RATIO } & $14.70 * * *$ & $15.32 * * *$ & $18.88 * * *$ & $19.52 * * *$ \\
\hline & 4.30 & 3.12 & 4.58 & 4.12 \\
\hline \multirow[t]{2}{*}{ CRISIS } & $-29.04 * * *$ & $-12.91 * * *$ & $-12.81 * * *$ & $-11.82 * * *$ \\
\hline & 10.46 & 3.14 & 3.82 & 2.96 \\
\hline \multirow[t]{2}{*}{ HERF_EQ } & $-5.29 * *$ & $-4.75 * * *$ & $-7.12 * * *$ & $-6.98 * * *$ \\
\hline & 2.14 & 1.56 & 2.42 & 1.78 \\
\hline \multirow[t]{2}{*}{$\mathrm{C}$} & 13.01 & $7.53 * * *$ & 6.34 & $5.58 *$ \\
\hline & 7.77 & 2.68 & 4.05 & 3.24 \\
\hline \multirow[t]{2}{*}{ CRISIS*OECD_RATING } & 2.56 & - & - & - \\
\hline & 2.75 & - & - & - \\
\hline \multirow[t]{2}{*}{ LOG(TOTAL_VALUE) } & -0.56 & - & - & - \\
\hline & 0.63 & - & - & - \\
\hline \multirow[t]{2}{*}{ CRISIS*HERF_DEBT } & 3.20 & - & - & - \\
\hline & 3.82 & - & - & - \\
\hline \multirow[t]{2}{*}{ CRISIS*DEBT_RATIO } & 3.42 & - & - & - \\
\hline & 6.55 & - & - & - \\
\hline \multirow[t]{2}{*}{ CRISIS*HERF_EQ } & -1.27 & - & - & - \\
\hline & 3.34 & - & - & - \\
\hline \multirow[t]{2}{*}{ HERF_DEBT } & 0.56 & - & - & - \\
\hline & 2.60 & - & - & - \\
\hline \multirow[t]{2}{*}{ OECD_RATING } & -0.39 & - & - & - \\
\hline & 2.53 & - & - & - \\
\hline Adjusted R-squared & 0.35 & 0.35 & 0.32 & 0.32 \\
\hline Durbin-Watson Stat & 1.78 & 1.75 & 1.64 & 1.63 \\
\hline
\end{tabular}

OLS, TSLS and GMM mean ordinary least square, two-stage least square and general methods of moments, respectively. The symbols $* * *, * *$, and * represent significance at $1 \%, 5 \%$, and $10 \%$, respectively where $\alpha$ is the intercept of the regression, $\beta_{1 \text { to } 11}$ are the coefficients of the explanatory variables and $v_{i}$ is the error term. The indices $i$ and $j$ represent the project and the associated country location, respectively. The variable Crisis is a dummy variable with a value of 0 for projects that reached financial closure before the financial crisis and 1 for those that reached closure after the financial crisis. The project size variable is in logarithmic form keeps it on the same scale as the other variables. The element $v_{i}$ stands for the disturbance and is assumed to be independently normally distributed.

Three successive iterative OLS, TSLS, and GMM calculations were performed to obtain a representative function that reflects only variables that are significant at least at the $10 \%$ level and do not show any endogeneity issues. The regression's results are reflected in Table 6.

\section{Determinants of debt duration}

The effect of the average debt duration and the previously explained variables are described in Eq. 3 below, which is defined with similar nomenclature as the previous equation. The regression results are also shown in Table 7 below.

$$
\begin{aligned}
& \text { Average Duration Debt } \\
& =\alpha+\beta_{1} \text {.Debt Ownership Concentration }{ }_{i} \\
& +\beta_{2} \cdot \text { Crisis }_{i}+\beta_{3} \cdot \log \left(\text { project size } \text { s }_{i}\right) \\
& +\beta_{4} \text {.Equity Ownership Concentration }{ }_{i} \\
& +\beta_{5} \text {. Debt Ratio }{ }_{i}+\beta_{6} \text {. CountryRating }_{j} \\
& +\beta_{7} \text {.Crisis }_{i} * \text { Country Rating } \\
& +\beta_{8} \text {.Crisis } * \text { EquityOwnership Concentration }{ }_{i} \\
& +\beta_{9} \text {.Crisis }_{i} * \text { Debt Ratio } i \\
& +\beta_{10} . \text { Crisis }_{i} * \log \left(\operatorname{Pr} \text { oject }_{\text {Size }}\right)+\beta_{11} \text {.Crisis }_{i} \\
& \text { * Average Duration Debt } t_{i}+v_{i}
\end{aligned}
$$


Table 8 Results of iterative regressions of debt ownership concentration (coefficients and standard errors)

\begin{tabular}{|c|c|c|c|c|}
\hline Dependent variable: debt concentration & Iteration 1 & Iteration 2 & TSLS & GMM \\
\hline \multirow[t]{2}{*}{$\mathrm{C}$} & $1.31 * * *$ & $1.02 * * *$ & $0.85^{* * *}$ & $0.79 * * *$ \\
\hline & 0.39 & 0.13 & 0.17 & 0.12 \\
\hline \multirow[t]{2}{*}{ LOG(TOTAL_VALUE) } & $-0.14 * * *$ & $-0.11 * * *$ & $-0.08 * * *$ & $-0.08 * * *$ \\
\hline & 0.03 & 0.02 & 0.02 & 0.02 \\
\hline \multirow[t]{2}{*}{ CRISIS*HERF_EQ } & $0.49 * * *$ & $0.36 * * *$ & $0.35 * * *$ & $0.22 * *$ \\
\hline & 0.18 & 0.10 & 0.13 & 0.11 \\
\hline \multirow[t]{2}{*}{ CRISIS*DEBT_RATIO } & $-0.85 * *$ & $-0.32 * * *$ & $-0.29 * *$ & $-0.14^{*}$ \\
\hline & 0.38 & 0.10 & 0.12 & 0.09 \\
\hline \multirow[t]{2}{*}{ CRISIS*LOG(TOTAL_VALUE) } & 0.03 & - & - & - \\
\hline & 0.04 & - & - & - \\
\hline \multirow[t]{2}{*}{ HERF_EQ } & -0.10 & - & - & - \\
\hline & 0.12 & - & - & - \\
\hline \multirow[t]{2}{*}{ CRISIS*AVG_DURATION_DEBT } & 0.01 & - & - & - \\
\hline & 0.01 & - & - & - \\
\hline \multirow[t]{2}{*}{ DEBT_RATIO } & 0.16 & - & - & - \\
\hline & 0.25 & - & - & - \\
\hline \multirow[t]{2}{*}{ OECD_RATING } & -0.06 & - & - & - \\
\hline & 0.13 & - & - & - \\
\hline \multirow[t]{2}{*}{ CRISIS*OECD_RATING } & -0.04 & - & - & - \\
\hline & 0.15 & - & - & - \\
\hline \multirow[t]{2}{*}{ AVG_DURATION_DEBT } & 0.00 & - & - & - \\
\hline & 0.01 & - & - & - \\
\hline \multirow[t]{2}{*}{ CRISIS } & 0.06 & - & - & - \\
\hline & 0.51 & - & - & - \\
\hline Adjusted R-Squared & 0.32 & 0.31 & 0.30 & 0.28 \\
\hline Durbin-Watson Stat & 2.21 & 2.07 & 2.08 & 2.03 \\
\hline
\end{tabular}

OLS, TSLS and GMM mean ordinary least square, two-stage least square and general methods of moments, respectively. The symbols $* * *, * *$, and * represent significance at $1 \%, 5 \%$, and $10 \%$, respectively

\section{Determinants of debt concentration}

The estimated equation for the determinants of the concentration of debt ownership is similar to Eq. 1 and is defined as follows:

\section{Debt Ownership Concentration}

$$
\begin{aligned}
& =\alpha+\beta_{1} \text {.Average Duration Debt }{ }_{i} \\
& +\beta_{2} \text {.Crisis }+\beta_{3} \cdot \log \left(\text { project size } \text { }_{i}\right) \\
& +\beta_{4} \text {.Equity Ownership Concentration }{ }_{i} \\
& +\beta_{5} \text {. Debt Ratio }{ }_{i}+\beta_{6} \text {. Country Rating }_{j} \\
& +\beta_{13} \text {.Crisis }_{i} * \text { CountryRating }_{j} \\
& +\beta_{14} \text {.Crisis }_{i} * \text { Ownership Concentration }{ }_{i} \\
& +\beta_{15} \text {.Crisis }_{i} * \text { Debt } \text { Ratio }_{i} \\
& +\beta_{16} \cdot \text { Crisis }_{i} * \log \left(\text { Project }_{\text {Size }}\right)+\beta_{17} \text {.Crisis }_{i} \\
& \text { * Average Duration Debt } t_{i}+v_{i}
\end{aligned}
$$

where as before, $\alpha$ is the intercept of the regression, $\beta_{1 \text { to } 11}$ are the coefficients of the explanatory variables and $v_{i}$ is the error term. The indices $i$ and $j$ represent the project and the associated country location, respectively. The outcomes of the two OLS iterations and subsequent TSLS and GMM calculations are shown in the Table 8 .

\section{Determinants of equity concentration}

The equation below describes the relationship between equity ownership concentration and the previously explained variables:

Equity Ownership Concentration

$$
\begin{aligned}
& =\alpha+\beta_{1} \text {.Average Duration Debt }{ }_{i} \\
& +\beta_{2} \text {.Crisis }+\beta_{3} \cdot \log \left(\text { project size } e_{i}\right) \\
& +\beta_{4} \text {.Debt Ownership Concentration } \\
& +\beta_{5} \text {.Debt Ratio }{ }_{i}+\beta_{6} \text {. Country Rating } \\
& +\beta_{7} \text {.Crisis }_{i} * \text { Country Rating } \\
& +\beta_{8} \text {.Crisis }_{i} * \text { Ownership Concentration }_{i} \\
& +\beta_{9} \text {.Crisis }_{i} * \text { Debt } \text { Ratio }_{i} \\
& +\beta_{10} \text {.Crisis }_{i} * \log \left(\text { Project }_{\text {Size }}\right)+\beta_{11} \text {.Crisis }_{i} \\
& \text { * Average Duration Debt } t_{i}+v_{i}
\end{aligned}
$$


Table 9 Results of iterative regressions of equity ownership concentration (coefficients and standard errors)

\begin{tabular}{|c|c|c|c|c|c|c|}
\hline Dependent: equity concentration & Iteration 1 & Iteration 2 & Iteration 3 & Iteration 4 & TSLS & GMM \\
\hline \multirow[t]{2}{*}{$\mathrm{C}$} & $1.50 * * *$ & $1.20 * * *$ & $0.89 * * *$ & $0.86^{* * * *}$ & $0.83 * * *$ & $0.78 * * *$ \\
\hline & 0.42 & 0.24 & 0.08 & 0.08 & 0.10 & 0.07 \\
\hline \multirow[t]{2}{*}{ AVG_DURATION_DEBT } & $-0.02 * * *$ & $-0.02 * * *$ & $-0.02 * * *$ & $-0.02 * * *$ & $-0.02 * * *$ & $-0.01 * * *$ \\
\hline & 0.01 & 0.00 & 0.00 & 0.00 & 0.01 & 0.00 \\
\hline \multirow[t]{2}{*}{ CRISIS } & $-1.62 * *$ & $-0.75^{* *}$ & $-0.45^{* *}$ & $-0.12 * *$ & $-0.12 *$ & $-0.11 * *$ \\
\hline & 0.60 & 0.31 & 0.23 & 0.06 & 0.07 & 0.05 \\
\hline \multirow[t]{2}{*}{ CRISIS*HERF_DEBT } & $0.55 * *$ & $0.37 * *$ & $0.37 * *$ & $0.29 * *$ & $0.32 *$ & $0.33 * * *$ \\
\hline & 0.21 & 0.14 & 0.14 & 0.13 & 0.19 & 0.09 \\
\hline \multirow[t]{2}{*}{ CRISIS*LOG(TOTAL_VALUE) } & $0.12 * *$ & $0.09 * *$ & 0.04 & & & \\
\hline & 0.05 & 0.04 & 0.03 & & & \\
\hline \multirow[t]{2}{*}{ LOG(TOTAL_VALUE) } & $-0.06^{*}$ & -0.04 & & & & \\
\hline & 0.04 & 0.03 & & & & \\
\hline \multirow[t]{2}{*}{ CRISIS*OECD_RATING } & 0.15 & - & - & - & - & - \\
\hline & 0.16 & - & - & - & - & - \\
\hline \multirow[t]{2}{*}{ HERF_DEBT } & -0.12 & - & - & - & - & - \\
\hline & 0.15 & - & - & - & - & - \\
\hline \multirow[t]{2}{*}{ CRISIS*DEBT_RATIO } & 0.24 & - & - & - & - & - \\
\hline & 0.43 & - & - & - & - & - \\
\hline \multirow[t]{2}{*}{ CRISIS*AVG_DURATION_DEBT } & 0.00 & - & - & - & - & - \\
\hline & 0.01 & - & - & - & - & - \\
\hline \multirow[t]{2}{*}{ DEBT_RATIO } & -0.10 & - & - & - & - & - \\
\hline & 0.28 & - & - & - & - & - \\
\hline \multirow[t]{2}{*}{ OECD_RATING } & -0.02 & - & - & - & - & - \\
\hline & 0.15 & - & - & - & - & - \\
\hline Adjusted R-Squared & 0.26 & 0.17 & 0.16 & 0.15 & 0.15 & 0.15 \\
\hline Durbin-Watson Stat & 1.79 & 1.73 & 1.76 & 1.81 & 1.83 & 1.84 \\
\hline
\end{tabular}

OLS, TSLS and GMM mean ordinary least square, two-stage least square and general methods of moments, respectively. The symbols $* * *, * *$, and $*$ represent significance at $1 \%, 5 \%$, and $10 \%$, respectively

where $\alpha, \beta_{1 \text { to } 11}, v_{i}$ and indices $i$ and $j$ represent the same variables as before. The three OLS iterations and subsequent TSLS and GMM calculations are shown in Table 9 below.

\section{Determinants of debt's interest rate}

A cross-sectional regression was performed, taking the interest rate as a dependent variable against the set of explanatory variables explained in "Model and data description" section. A stepwise procedure was implemented; all variables with the lowest significant $p$-values were removed in successive iterations until the remaining ones were at the $10 \%$ significance level.

$$
\begin{aligned}
& \text { Interest rate }=\alpha+\beta_{1} \text { Average Duration Debt }{ }_{i} \\
& +\beta_{2} \text { Crisis }_{i}+\beta_{3} \log \left(\text { project size } \text { s }_{i}\right) \\
& +\beta_{4} \text { Ownership Concentration }_{i} \\
& +\beta_{5} \text { Debt Concentration }_{i}+\beta_{6} \text { Country Rating }_{j}
\end{aligned}
$$

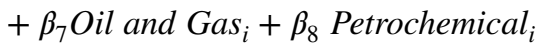

$$
\begin{aligned}
& +\beta_{9} \text { Mining }_{i}+\beta_{10} \text { Expansion }_{i} \\
& \beta_{11} \text { Debt Ratio }_{i}+\beta_{12} \text { Crisis }_{*} \text { Debt Ratio } i \\
& +\beta_{13} \text { Crisis }_{i} * \text { Counbtry Rating } \\
& \beta_{14} \text { Crisis } * \text { Ownership Concentration }_{i} \\
& +\beta_{15} \text { Crisis }_{i}
\end{aligned}
$$

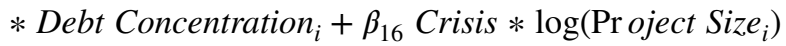

$$
\begin{aligned}
& +\beta_{17} \text { Crisis }_{i} \\
& \text { * Average Duration Debt } t_{i}+v_{i}
\end{aligned}
$$




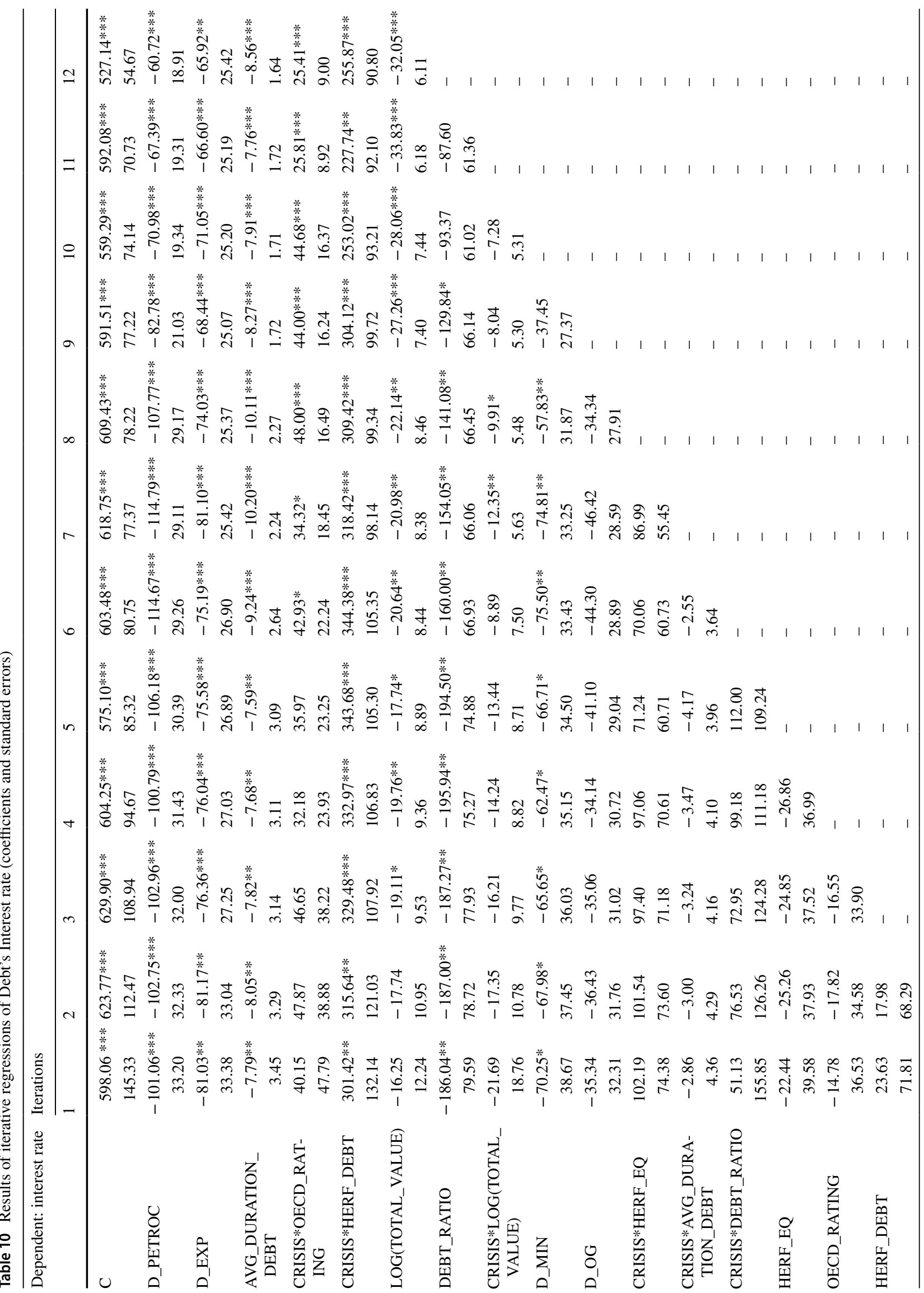




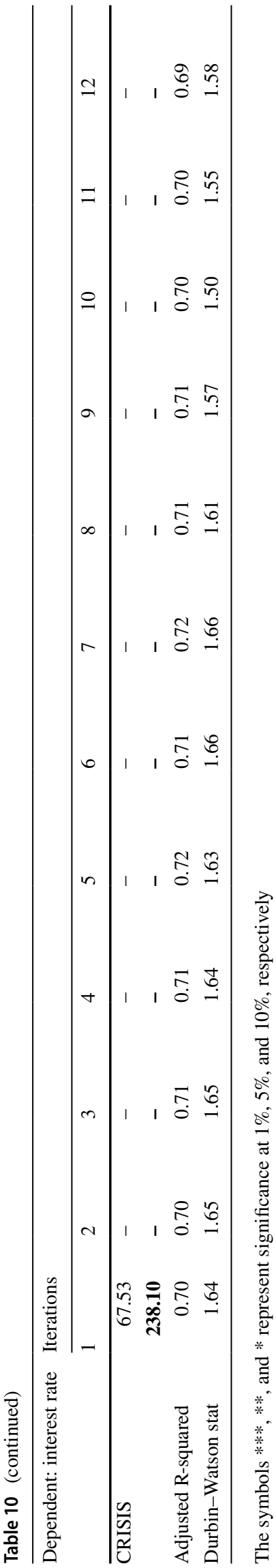

where $\alpha$ is the intercept of the regression, $\beta_{1}$ to 17 are the coefficients of the explanatory variables and $v_{i}$ is the error term. The indices $i$ and $j$ represent the project and the associated country location, respectively. The variables Crisis, Oil and Gas, Petrochemical, Mining, Expansion, Transportation and Renewable are dummy variables with values of 0 or 1 . The variable pertaining to project size is in logarithmic form to keep it on the same scale as the other variables.

Twelve iterative regressions were implemented to obtain a representative function with variables that are at least at the $10 \%$ significance level. The regression's results are reflected in Table 10.

\section{References}

1. Akbiyikli, R., Eaton, D., Turner, A.: Project finance and the private finance initiative (PFI). J. Struct. Finance 12(2), 67 (2006)

2. Almutairi, H.: Competitive advantage through taxation in GCC countries. Int. Bus. Econ. Res. J. 13(4), 769 (2014)

3. Al-Rashed, M., Abdel-Jawad, M.: Public-private partnership in water desalination. Desalin. Water Treat. 5(1-3), 252-256 (2009)

4. Anderson, T.W., Hsiao, C.: Formulation and estimation of dynamic models using panel data. J. Econ. 18, 47-82 (1982)

5. Azmat, S., Skully, M., Brown, K.: Issuer's choice of Islamic bond type. Pac. Basin Finance J. 28, 122-135 (2014)

6. Bevan, A.A., Danbolt, J.: Capital structure and its determinants in the United Kingdom. Appl. Financ. Econ. 12(3), 159-170 (2002)

7. Bezen, Y., Aslan, B.: Project finance in Turkey's energy sector: a Turkish delight for financiers. Law Financ. Mark. Rev. 4(3), 272-275 (2010)

8. Biancone, P.P., Radwan, M.: Sharia-compliant financing for public utility infrastructure. Util. Policy 52, 88-94 (2018)

9. Bradley, M., Jarrell, G.A., Kim, E.H.: On the existence of an optimal capital structure: theory and evidence. J. Finance 39(3), 857-878 (1984)

10. Buscaino, V., Caselli, S., Corielli, F., Gatti, S.: Project finance collateralised debt obligations: An empirical analysis of spread determinants. Eur. Financ. Manage. 18(5), 950-969 (2012)

11. Byoun, S., Zhaoxia, X.: Contracts, governance, and country risk in project finance: theory and evidence. J. Corp. Finance 26, 124-144 (2014)

12. Byoun, S., Kim, J., Yoo, S.S.: Risk management with leverage: evidence from project finance. J. Financ. Quant. Anal. 48(2), 549-577 (2013)

13. Caliński, T., Harabasz, J.: A dendrite method for cluster analysis. Commun. Stat. Theory Methods 3(1), 1-27 (1974)

14. Cantillo, M., Wright, J.: How do firms choose their lenders? An empirical investigation. Rev. Financ. Stud. 13(1), 155-189 (2000)

15. Corielli, F., Gatti, S., Steffanoni, A.: Risk shifting through nonfinancial contracts: effects on loan spreads and capital structure of project finance deals. J. Money Credit Bank. 42(7), 12951320 (2010)

16. DeAngelo, H., Masulis, R.W.: Optimal capital structure under corporate and personal taxation. J. Financ. Econ. 8, 3-29 (1980)

17. Deesomsak, R., Paudyal, K., Pescetto, G.: The determinants of capital structure: evidence from the Asia Pacific region. J. Multinat. Financ. Manag. 14(4), 387-405 (2004) 
18. Degryse, H., de Goeij. P., Kappert, P.: The impact of firm and industry characteristics on small firm's capital structure: evidence from dutch panel data" Center Discussion Paper, No. 2009-21

19. Dobbs, R., et al.: Infrastructure Productivity: How to Save $\$ 1$ Trillion a Year? McKinsey Global Institute, McKinsey Co., NewYork (2013)

20. Esty, B.C.: The economic motivations for using project finance. Harv. Bus. School 28, 1-42 (2003)

21. Esty, B.C.: Why study large projects? An introduction to research on project finance. Eur. Financ. Manag. 10(2), 213-224 (2004)

22. Esty, B.: An Overview of Project Finance and Infrastructure Finance-2014 Update. HBS Case 214083 (2014)

23. Esty, B.C., Megginson, W.L.: Creditor rights, enforcement, and debt ownership structure: evidence from the global syndicated loan market. J. Financ. Quant. Anal. 38(01), 37-60 (2003)

24. Finnerty, J.D.: Project Financing: Asset-Based Financial Engineering. Wiley, New York (2007)

25. Ganguli, S.K.: Capital structure-Does ownership structure matter? Theory and Indian evidence. Stud. Econ. Finance 30(1), 56-72 (2013)

26. Gatti, S.: Project finance in theory and practic (2008)

27. Ghoddusi, H., Khoshroo, S.: Islamic inance and the energy sector. Available at SSRN 2565812 (2015)

28. Girardone, C., Snaith, S.: Project finance loan spreads and disaggregated political risk. Appl. Financ. Econ. 21(23), 1725-1734 (2011)

29. Grassa, R., Miniaoui, H.: Corporate choice between conventional bond and Sukuk issuance evidence from GCC countries. Res. Int. Bus. Finance 45, 454-466 (2018)

30. Guedes, J., Opler, T.: The determinants of the maturity of corporate debt issues. J. Finance 51(5), 1809-1833 (1996)

31. Harris, M., Raviv, A.: The theory of capital structure. J. Finance 46(1), 297-355 (1991)

32. Hertog, S.: The private sector and reform in the Gulf Cooperation Council (2013)

33. Holtz-Eakin, D., Newey, W., Rosen, H.S.: Estimating vector autoregressions with panel data. Econometrica 56, 1371-1395 (1988)

34. Houston, J., James, C.: Bank information monopolies and the mix of private and public debt claims. J. Finance 51(5), 1863-1889 (1996)

35. Jensen, M.C., Meckling, W.H.: Theory of the firm: managerial behavior, agency costs and ownership structure. J. Financ. Econ. 3(4), 305-360 (1976)

36. Kingdom of Saudi Arabia, VISION 2030. http://vision2030.gov. sa/en/ntp. Accessed 18 June 2016

37. Kleimeier, S., Megginson, W.L.: An empirical analysis of limited recourse project finance. University of Oklahoma, Michel F. Price College of Business Working Paper Series (2001)
38. Krishnaswami, S., Spindt, P.A., Subramaniam, V.: Information asymmetry, monitoring, and the placement structure of corporate debt. J. Financ. Econ. 51(3), 407-434 (1999)

39. Jiraporn, P., Kim, J.C., Kim, Y.S.: Dividend payouts and corporate governance quality: an empirical investigation. Financ. Rev. 46(2), 251-279 (2011)

40. Leigland, J., Russell, H.: Another lost decade? Effects of the financial crisis on project finance for infrastructure. No. 10541. The World Bank (2009)

41. Lin, C., et al.: Corporate ownership structure and the choice between bank debt and public debt.”. J. Financ. Econ. 109(2), 517-534 (2013)

42. Lubin, D.A., Esty, D.C.: Lessons for leaders from previous gamechanging megatrends. Harvard Bus. Rev. 88(5), 42-50 (2010)

43. Mahmudova, M., Sharma, G., Rey, Y.: Global infrastructure finance review. Infrastruct. J. (2011)

44. Modigliani, F., Miller, M.H.: The cost of capital, corporation finance and the theory of investment. Am. Econ. Rev. 48(3), 261-297 (1958)

45. Mustafa, A.: Public-private partnership: an alternative institutional model for implementing the private finance initiative in the provision of transport infrastructure. J. Struct. Finance 5(1), 56-71 (1999)

46. Myers, S.C.: The capital structure puzzle. J. Finance 39(3), 575$592(1984)$

47. Pierru, A., Roussanaly, S., Sabathier, J.: Capital structure in LNG infrastructures and gas pipelines projects: empirical evidences and methodological issues. Energy Policy 61, 285-291 (2013)

48. Rajan, R.G., Zingales, L.: What do we know about capital structure? Some evidence from international data. J. Finance 50(5), 1421-1460 (1995)

49. Scannella, E.: Project finance in the energy industry: New debtbased financing models. Int. Bus. Res. 5(2), 83-93 (2012)

50. Silvers, J.B.: Liquidity, risk and duration patterns in corporate financing. Financ. Manag. 5, 54-64 (1976)

51. Sorge, M. Stress-testing financial systems: an overview of current methodologies (2004)

52. Taub, A.J.: Determinants of the firm's capital structure. Rev. Econ. Stat. 410-416 (1975)

53. Titman, S., Wessels, R.: The determinants of capital structure choice. J. Finance 43(1), 1-19 (1988)

54. Tyson, J., et al.: The effects of the financial crisis on public-private partnerships. International Monetary Fund Paper 09-144 (2009)

55. Wagenvoort, R., De Nicola, C., Kappeler, A.: Infrastructure finance in Europe: Composition, evolution and crisis impact. EIB papers 15.1 (2010)

56. West, J.: Islamic finance and the resources sector: a natural fit for project finance. J. Islam. Econ. Bank. Finance 9(2), 9-26 (2013)

57. Yescombe, E.R.: Public-Private Partnerships: Principles of Policy and Finance. Butterworth-Heinemann, Oxford (2011) 